\title{
Makna Kebahagiaan pada Karyawan Wanita Usia Madya di Kumala Laundry Kota Banjarmasin
}

\author{
Nangimatus Sa'adah, Siti Faridah dan Yulia Hairina \\ Universitas Islam Negeri (UIN) Antasari Banjarmasin
}

\begin{abstract}
Employee happiness greatly affects their performance. With higher happiness, middle-aged employees will be more optimal so that they can make a positive contribution to their family and the surrounding environment. The purpose of this research is to know a picture of happiness and to identify the happiness factor felt by middle age female employees at Kumala Laundry, Banjarmasin City. This research is field research, qualitative research methods. The research subjects were 2 women working at Kumala Laundry in Banjarmasin City. Data collection techniques using interviews and observations. The results obtained showed that happiness in middle age female employees was in the cognitive and affective aspects. From the cognitive aspects of subjects $S$ and $A$ have different life satisfaction. The affective aspect of the two subjects also had different results, but they both accepted and were grateful for what they got. The factors that affect the happiness of subject $S$ are money, marriage, social life, health and religion, while subject $A$ is money, marriage, age, health and religion
\end{abstract}

Keywords: Happiness; middle age; employees.

\begin{abstract}
Abstrak
Kebahagiaan karyawan sangat mempengaruhi kinerjanya. Dengan kebahagiaan yang lebih tinggi, maka karyawan yang berusia madya akan lebih optimal sehingga dapat memberikan kontribusi positif bagi keluarga dan lingkungan sekitarnya. Tujuan dari penelitian ini ialah agar dapat mengetahui gambaran kebahagiaan dan mengidentifikasi faktor kebahagiaan yang dirasakan karyawan wanita usia madya di Kumala Laundry Kota Banjarmasin. Penelitian ini merupakan penelitian lapangan, dengan menggunakan metode kualitatif. Subjek dalam penelitian ini berjumlah dua orang wanita yang bekerja di Kumala Laundry Kota Banjarmasin. Teknik pengumpulan data menggunakan wawancara dan observasi. Hasil penelitian yang didapatkan, kebahagiaan pada karyawan wanita usia madya ada pada aspek kognitif dan aspek afektif. Dari aspek kognitif subjek S dan A memiliki kepuasan hidup yang berbeda. Aspek afektif dari kedua subjek juga memiliki hasil berbeda yang namun mereka sama-sama menerima dan bersyukur atas apa yang mereka dapatkan. Faktor-faktor yang mempengaruhi kebahagiaan subjek S adalah uang, perkawinan, kehidupan sosial, kesehatan dan agama, sedangkan subjek A adalah uang, perkawinan, usia, kesehatan dan agama.
\end{abstract}

Kata kunci: Kebahagiaan; usia madya; karyawan 
Manusia seorang makhluk yang memiliki dua dimensi (double dimension) yaitu dimensi rohani serta dimensi jasmani, yang lahir dalam keadaan fitrah. Fitrah yang dimaksud bukan hanya suci dari noda dan dosa yang ada akan tetapi lebih pada selengkapnya kemampuan kodrati yang bersifat spiritual. Dengan potensi inilah manusia diberi kepercayaan untuk menjadi Khalîfah Allah fi al-ardh yang memiliki peran untuk berfungsi ketuhanan di muka bumi. Manusia tidak hanya sekedar menjalani kehidupan di dunia ini dengan naluri dan instink, namun diperlukan kepekaan terhadap lingkungan sekitar dan permasalahaan yang dihadapi (Raharjo, 2012).

Bahagia, pada dasarnya merupakan fitrah yang merupakan bawaan alami manusia. Hal ini diartikan jika bahagia merupakan suatu hal yang menempel pada diri manusia dan tidak dapat terpisahkan dari dalam diri manusia. Bahagia merupakan sesuatu yang sudah sepantasnya dimiliki oleh manusia berdasarkan fitrahnya yang diciptakan dari berbagai kelebihan dan disempurnakan oleh Allah SWT. Manusia merupakan makhluk mulia dan diciptakan secara istimewa sebanding dengan berbagai ciptaan Allah SWT lainnya (Rahman, 2012)

Hal ini telah dinyatakan oleh Allah SWT. dalam Q.S. al-Isrō/17: 70. sebagai berikut:

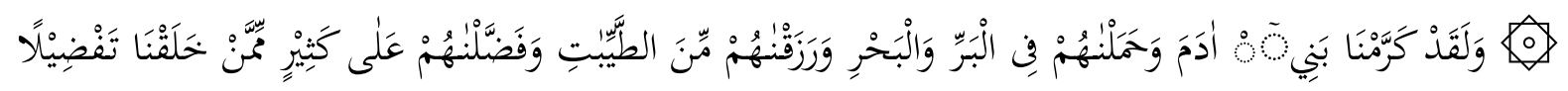

Artinya: "Dan sungguh, Kami telah memuliakan anak cucu Adam, dan Kami angkut mereka di darat dan di laut, dan Kami beri mereka rezeki dari yang baik-baik dan Kami lebihkan mereka di atas banyak makhluk yang Kami ciptakan dengan kelebihan yang sempurna."

Kebahagiaan dalam Kamus Besar Bahasa Indonesia (KBBI) dimaknai sebagai suatu kondisi maupun perasaan senang serta kedamaian dalam hidup yang bersifat lahir maupun batin (Departemen Pendidikan Nasional, 2008). Bahagia sendiri menurut arti yang diterjemahkan dari bahasa Arab, "al-sa' $\bar{\alpha} d a h^{\prime}$ yang berarti bahagia atau mujur. Makna "bahagia" tidak sama dengan makna "senang." Dalam filsafat makna "bahagia" bisa memiliki arti "kenyamanan" atau "kenikmatan" spiritual sempurna serta rasa kepuasan. Tidak memiliki beban didalam pikiran sehingga seseorang memiliki perasaan tenang dan damai. Konsep bahagia memiliki sifat abstrak serta tidak bisa di sentuh maupun di raba. Kebahagiaan erat berhubungannya pada kejiwaan seseorang (Rahman, 2012). 
Allah SWT. menerangkan dalam Q.S. al-Hajj/22: 77 yang berbunyi:

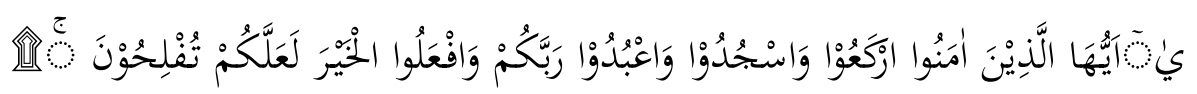

Artinya: "Wahai orang-orang yang beriman! Rukuklah, sujudlah, dan sembahlah Tuhanmu; dan berbuatlah kebaikan, agar kamu beruntung."

Kemudian Allah SWT. juga berfirman dalam Q.S. al-Baqarah/2: 112.

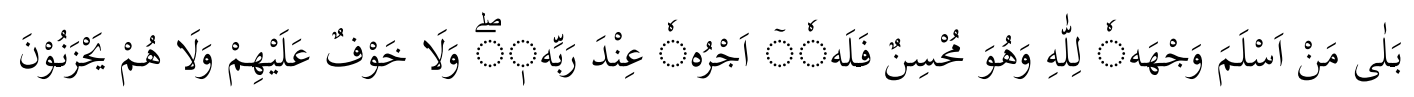

Artinya: "Tidak! Barangsiapa menyerahkan diri sepenuhnya kepada Allah, dan dia berbuat baik, dia mendapat pahala di sisi Tuhannya dan tidak ada rasa takut pada mereka dan mereka tidak bersedih hati."

Dari firman Allah SWT tersebut dapat disimpulkan jika kebahagiaan yang terdapat didalam agama Islam terletak pada kepatuhan manusia terhadap tuhannya yaitu Allah SWT. Dengan amal ibadah, ketaatan terhadap Allah SWT dan ketetapan hati agar tidak pernah lupa dalam mengingat-Nya, berserah diri pada-Nya dan berperilaku baik pada sesama manusia. Kehidupan seseorang makna kata bahagia itu adalah sebagai tujuan utama kehidupan, baik itu bahagia di dunia maupun di akhirat. Hidup bahagia merupakan perwujudan kebaikan diri dan harmonisasi hubungan antara sesama manusia. Tetapi, realitanya di dalam kehidupan seseorang banyak bermacam hal yang menjadikan seseorang tidak dapat merasakan kebahagiaan, seperti keadaan di mana seseorang yang sudah berkecukupan masih belum merasakan kebahagiaan secara jasmani dan rohani, dan itu biasanya disebabkan karena meraka belum puas atau tidak bersyukur dengan keadaan mereka (Bakar, 2008)

Dalam hal ini kebahagiaan sendiri kelihatanya sesuatu hal yang menjadi keinginan semua orang. Kendati kebahagiaan menjadi cita-cita bagi manusia, tetapi pada nyatanya pencapaiaan makna bahagia sendiri bukan merupakan sesuatu yang bisa dilakukan dengan mudah, karena cukup banyak juga manusia merasa sedih dan tidak berbahagia, kemudian berupaya agar menemukan jalan untuk bahagia. Hal ini juga dialami oleh kaum perempuan.

Permasalahan tentang kebahagiaan ini bisa terjadi pada orang yang berada pada usia madya. Usia madya pada umumnya diartikan sebagai usia paruh baya. Usia paruh baya dilihat sebagai usia yang terjadi di umur 40 sampai dengan 60 tahun. Usia ini memiliki keunikan pada pribadi serta sosial seseorang yang meliputi, masa dewasa madya yang bertransisi, ketika laki- 
laki maupun perempuan melepaskan kriteria jasmani dan perilakunya pada masa dewasa dan memasuki perilaku baru. Pada masa ini manusia biasanya cenderung akan lebih memperhatikan aspek agama dibandingkan dengan masa dewasanya,hal ini juga dipengaruhi oleh kebutuhan pribadi dan sosial manusia itu sendiri (Yudrik, 2012).

Pada usia ini juga dikenal dengan era rentan stress. Adaptasi dengan bebas pada peran maupun gaya hidup yang berubah terkhusus jika diikuti dengan adanya perubahan fisik pada manusia yang dapat merusak nemeostatis fisik dan psikologi yang menhantarkan pada masa stress, hal ini akan terjadi apabila sejumlah adaptasi pokok tersebut harus dilakukan dirumah, bisnis serta pada aspek besosial dalam kehidupan mereka (Yudrik, 2012).

Hal ini juga terjadi pada karyawan wanita yang berusia madya di sebuah perusahaan yang terletak di kota Banjarmasin. Perusahaan tersebut dikenal dengan nama CV. Kumala Artha Media atau lebih sering dikenal dengan CV. Kumala Laundry. Perusahaan ini ialah perusahan yang berkembang pada jalur bisnis dan jasa, khususnya Laundry atau jasa bantu dengan konsep pelayanan cuci dan setrika per kilogram yang sekarang ini berkembang pesat khususnya di Banjarmasin.

CV. Kumala Artha Media adalah pemilik merk Franchise Kumala Laundry yang telah sudah memiliki daftar pada Direktorat Jendral HAKI No. Reg.EJ12201600026. dan Dry Cleaning Franchise Indonesia Waralaba Laundry dirintis di Banjarmasin sejak April 2009 dan sekarang sudah tersebar di beberapa tempat, seperti Banjarmasin, Banjarbaru, Martapura dan Balikpapan. Di Banjarmasin Kumala Laundry memiliki cabang sekitar 53 cabang, dan setiap cabang memiliki kurang lebih 9 sampai 11 orang karyawan yang terdiri dari usia sekitar 20 tahun sampai 50 tahun. Setiap cabang juga memiliki karyawan yang tidak hanya terdiri satu jenis kelamin melainkan terdiri dari laki-laki dan perempuan. Dari wawancara yang dilakukan dengan manajer Kumala Laundry, setiap tempat kerja memiliki peraturan yang telah ditetapkan atasan, seperti jam kerja yang ditetapkan di Kumala Laundry yaitu 12 jam kerja dan dibagi menjadi dua shif.

Peneliti tertarik untuk meneliti karyawan wanita yang berusia madya karena menurut peneliti ketenangan batin dan kebahagiaan itu menjadi satu hal yang seharusnya sudah dimiliki 
oleh seseorang yang sudah berusia madya, karena di usia mereka itu sangat rentan dengan stres.

Dengan tingkat kebahagiaan yang lebih tinggi, maka diharapkan karyawan yang berusia madya akan lebih maksimal ketika menjalankan bermacam peran yang disandang agar dapat memberikan kontribusi positif terutama bagi keluarga dan lingkungan sekitarnya, Oleh sebab itu peneliti merasa terdorong dan terpanggil untuk melakukan penelitian yang berjudul “Makna Kebahagiaan pada Karyawan Wanita Usia Madya di Kumala Laundry Kota Banjarmasin".

\section{Metode}

Peneliti menggunakan jenis penelitian lapangan yang biasa disebut field research dengan pendekatan kualitatif, yakni data yang dikumpulkan berbentuk deskriptif berupa kalimat ataupun kata-kata dan gambar. Apabila terdapat angka pada penelitian hanya bersifat sebagai data pendukung. Perolehan data mencakup transkrip wawancara, catatan kegiatan yang dilakukan di lapangan, gambar, dokumen pribadi dan lain sebagainya (Basrowi \& Suwandi, 2008). Penggunaan jenis dan pendekatan penelitian ini bertujuan agar dapat memperoleh gambaran dan faktor-faktor apa saja yang dapat mempengaruhi kebahagiaan pada karyawan wanita usia madya di Kumala Laundry Kota Banjarmasin.

\section{H a s i 1}

Penelitian ini menggunakan penelitian kualitatif sebagai objek penelitian dan karyawan wanita paruh baya (40-50 tahun) sebagai objek penelitian. Peneliti melakukan wawancara terhadap dua karyawan wanita paruh baya yang isinya meliputi deskripsi kebahagiaan dan faktor-faktor yang mempengaruhi kebahagiaan. Berikut gambaran topik tersebut:

\section{Tabel 1}

Tabel Identitas Subjek Penelitian

\begin{tabular}{|c|l|c|l|l|l|c|}
\hline No & Subjek & Usia & Pendidikan & Pekerjaan & Lama Bekerja & Alamat \\
\hline 1. & S & 46 Tahun & S1 Ekonomi & Karyawan & 3 Tahun & Banjarmasin \\
\hline
\end{tabular}




\begin{tabular}{|l|l|l|l|l|l|l|}
\hline 2. & A & 49 Tahun & SMA & Karyawan & 5 Tahun & Banjarmasin \\
\hline
\end{tabular}

berdasarkan hasil observasi dan wawancara pada kedua subjek. yaitu sebagai berikut:

\section{Tabel 2}

\section{Penyajian Hasil Penelitian}

\begin{tabular}{|c|c|c|}
\hline Penyajian Data & Subjek S & Subjek A \\
\hline Gambaran Kebahagiaan & $\begin{array}{l}\text { Dari hasil wawancara subjek } S \\
\text { mendefinisikan bahagia adalah } \\
\text { ketika subjek memiiki apa yang } \\
\text { diinginkannya, seperti memiliki } \\
\text { kelimpahan harta, mempunyai } \\
\text { suami yang bertanggung jawab } \\
\text { dan anak-anaknya bisa hidup } \\
\text { sukses dengan meraih cita- } \\
\text { citanya dan bisa membuat } \\
\text { orang lain bahagia atau } \\
\text { memberikan manfaat kepada } \\
\text { sesama manusia yaitu dengan } \\
\text { berbagi. Meskipun subjek } S \\
\text { belum bisa memiliki apa yang } \\
\text { diinginkannya, menurut subjek } \\
S \text { saat ini subjek } S \text { bisa merasa } \\
\text { lebih bahagia dari sebelumnya } \\
\text { dan subjek } S \text { merasa bersyukur } \\
\text { dengan keadaanya sekarang }\end{array}$ & $\begin{array}{l}\text { Kebahagiaan yang didefinisikan } \\
\text { oleh Subyek A adalah ketika } \\
\text { Allah mengabaikan doa ketika } \\
\text { melihat orang tua dan anggota } \\
\text { keluarganya dalam keadaan } \\
\text { sehat. Sekalipun tidak satu atap } \\
\text { dengan orang tuanya, ketika } \\
\text { Subjek A mengetahui bahwa } \\
\text { beritanya sehat, Subjek A akan } \\
\text { berbahagia, dan ketika beriman } \\
\text { kepada Allah, Subjek A akan } \\
\text { berbahagia. } \\
\text { membahagiakan orang lain atau } \\
\text { membawa manfaat bagi orang } \\
\text { lain yaitu dengan berbagi. } \\
\text { Melalui keimanan yang saleh, A } \\
\text { juga akan merasa senang, } \\
\text { menikmati dan menghargai apa } \\
\text { yang dimilikinya, serta } \\
\text { bersabar, beriman dan ikhlas } \\
\text { pada anugerah Allah dan } \\
\text { aturan Allah. }\end{array}$ \\
\hline
\end{tabular}

$\begin{array}{llll}\text { Faktor-Faktor Kebahagiaan } & \text { 1. Memiliki Kelimpahan } & \begin{array}{l}\text { 1. Memiliki Banyak Uang } \\ \text { Materi }\end{array} & \text { 2. Pernikahan } \\ & \begin{array}{l}\text { 2. Pernikahan } \\ \text { 3. Agama }\end{array} & \text { 3. Pendidikan } \\ \text { 4. Kesehatan dan Kehidupan } & & \\ & \text { Lebih Baik } & \end{array}$

\section{Pembahasan}

Subjek S dan A adalah seorang karyawan wanita berusia madya yang bekerja di Kumala Laundry Kota Banjarmasin. Menurut Wirawan, Sumber daya manusia adalah sumber 
daya yang digunakan untuk memobilisasi dan mengkoordinasikan sumber daya lain untuk mencapai tujuan organisasi. Dari ungkapan tersebut dapat disimpulkan bahwa karyawan atau sumber daya manusia memiliki potensi yang luar biasa untuk melampaui sumber daya organisasi lainnya karena memiliki kemampuan fisik, kemampuan mental, kemampuan karakteristik, kemampuan pengetahuan dan keterampilan, serta pengalaman hidup (Abdullah, 2014). Dengan pengertian tersebut betapa pentingnya peran seorang karyawan bagi kemajuan sebuah perusahaan atau organisasi.

Dari hasil observasi kedua subjek memiliki gambaran kebahagiaan yang berbeda. Hasil observasi menunjukan bahwa subjek $S$ lebih bahagia ketika semua keinginannya bisa terpenuhi sedangkan subjek A lebih bahagia ketika bisa lebih dekat dengan Tuhan. Dari hasil wawancara dengan kedua subjek juga terdapat beberapa penemuan mengenai makna bahagia. Subjek S mendefinisikan bahagia ketika mempunyai kelimpahan materi atau mendapatkan semua yang diinginkan, memiliki pendamping hidup yang bertanggung jawab dan bisa melihat anak-anaknya sukses. Sedangkan pengertian kebahagiaan menurut subjek A adalah ketika Tuhan mengijinkan shalat, melihat anggota keluarga sehat dan beragama di jalan Allah.

Dari hasil penelitian untuk aspek acceptance (sikap menerima), Dari dua subjek samasama saling bersyukur dan bisa menerima dengan keadaan mereka, namun dilihat dari segi penerimaan diri yang berbeda-beda. Sedangkan aspek affection (kasih sayang), Dari hasil penelitian yang telah dilakukan pada subjek $S$ dan A dalam mengaplikasikan rasa kasih sayangnya dalam keseharian yaitu dengan saling berbagi terhadap sesama, serta saling menghormati terhadap sesama teman kerja atau lingkungan sosial. Selanjutnya adalah aspek achievement (prestasi), Dari hasil penelitian yang telah dilakukan pada subjek S dan A mempunyai tujuan hidup yang berbeda, kepuasan terhadap tercapainya sebuah tujuan didapatkan dari subjek A, perasaan bahagia karena bisa memiliki kembali keluarga yang utuh membuat subjek A selalu bersyukur kepada Allah SWT. karena tujuan hidup subjek A di usia madya adalah memiliki keluarga yang harmonis dan ketenangan hati. Sedangkan subjek S masih merasa belum cukup puas dengan tujuan hidupnya, karena tujuan hidup subjek $S$ di usia madya adalah memiliki usaha sendiri dan bisa melihat anak-anaknya bisa sukses. Andrews dan McKennell mengutip dari Deviana Maharani, mengatakan bahwa kebahagiaan 
memiliki dua aspek, yaitu aspek afektif dan aspek kognitif. Bentuk emosional meliputi kegembiraan, kegembiraan, kepuasan dan emosi positif lainnya. Aspek emosional dibagi menjadi dua aspek yaitu pengaruh positif dan pengaruh negatif. Aspek kognitif diekspresikan sebagai kepuasan dalam berbagai bidang kehidupan, seperti kepuasan dalam bidang keluarga atau pekerjaan dan pengalaman memuaskan lainnya (Deviana, 2015).

Dari hasil observasi dan wawancara ditemukan bahwa pembawaan diri ketika wawancara pada kedua subjek berbeda. Ketika wawancara subjek A lebih tenang pembawaanya dari pada subjek S yang sangat emosional ketika dilakukannya wawancara. Dalam hal ini dapat disimpulkan bahwa pengalaman hidup dari masa lalu yang didapatkan dari kedua subjek memberikan dampak emosi yang berbeda. Keinginan untuk hidup lebih baik dimasa depan didapatkan pada kedua subjek, jika subjek S dimasa tuanya nanti ingin bisa memiliki usaha sendiri dan bisa melihat anak-anaknya sukses, keinginan berbeda didapatkan dari subjek A yang ingin bisa hidup dengan lebih bahagia bersama keluarganya dan tenang dengan lebih mendekatkan diri kepada Allah SWT, kemudian faktor kebahagiaan dimasa sekarang dapat ditemukan pada subjek S dan A, karena lingkungan kedua subjek sama-sama memberikan dampak positif pada kehidupan yang mereka jalani sehingga membuat kedua subjek sama-sama menjalani kehidupan dengan cara selalu berfikir positif dan selalu bersyukur.

Untuk mempelajari faktor-faktor yang mempengaruhi kebahagiaan, penelitian ini didasarkan pada teori Seligman. Seligman mengomentari temuan tentang bagaimana lingkungan eksternal memengaruhi kebahagiaan yakni

Uang, Penilaian seseorang terhadap uang dapat memengaruhi kebahagiaan seseorang (Mahmudah, 2016). Subjek S sangat setuju dengan anggapan bahwa uang adalah faktor kebahagiaan, Sedangkan subjek A salah satu faktor yang membuktikan kebahagiaan adalah uang.

Perkawinan, perkawinan sangat erat hubungannya dengan kebahagiaan (Mahmudah, 2016). Menurut subjek S Status seorang janda tidak benar-benar merasakan kebahagiaan, Sedangkan hasil temuan yang didapat dari subjek A adalah pernikahan menjadi satu hal yang penting untuk merasakan kebahagiaan. 
Kehidupan sosial, Keterampilan sosial yang meningkat pada orang yang bahagia mungkin menjadi alasan mengapa orang bisa berpikir lebih positif dalam hidup. Karena berdasarkan peringkat mereka sendiri dan teman, mereka mendapat skor tertinggi dalam interaksi (Mahmudah, 2016). Penemuan dari subyek S, subjek S Lebih suka di keramaian dan lebih nyaman daripada menghabiskan waktu sendirian, Sedangkan subjek A Lebih nyaman daripada menghabiskan waktu senidrian daripada hanya bersosialisasi atau kumpul-kumpul dengan teman atau tetangga.

Emosi negatif, dalam hal ini emosi negatif yang dirasakan subjek $S$ menjadi emosi positif ketika sedang menghabiskan waktu berkumpul bersama teman-teman dan keluarga. Sedangkan subjek A lebih memilih mengalihkan emosi negatifnya dengan lebih mendekatkan diri kepada Allah SWT dan selalu berusaha berfikir positif dalam setiap keadaan.

Usia, perasaan puas dengan bertambahnya usia ditemukan pada subjek A, yang merasa cukup puas dengan kebahagiaan dan kehidupan yang dijalani saat ini, Sedangkan perasaan belum cukup puas di usia madya didapatkan dari subjek $\mathrm{S}$ yang belum bisa merasakan kebahagiaan yang sempurna diusia madya ini karena keinginan yang belum terwujudkan.

Kesehatan, Keinginan untuk selalu hidup lebih sehat ditemukan dari subjek S dan A, yang sama-sama menganggap bahwa kesehatan di usia madya itu adalah hal yang penting yang harus dijaga. Pendidikan, iklim, ras dan jenis kelamin, dalam penelitian ini tidak ditemukannya bahwa salah satu faktor utama dalam meraih kebahagian bagi subjek $\mathrm{S}$ dan $\mathrm{A}$ adalah pendidikan.

Agama, menurut Seligman ada hubungan yang lebih mendasar, agama memenuhi orang dengan harapan akan masa depan dan menciptakan makna dalam hidup (Mahmudah, 2016). Itu sesuai dengan temuan yang didapat dari subjek A. Subjek A Menjadi individu yang religius Sedangkan dalam penemuan yang didapat dari subjek $S$ adalah termasuk individu yang dalam shalat lima waktu, tingkat keyakinan beragama masih sangat rendah subjek $S$ mengaku masih menjalankannya, meski kadang-kadang ada yang terlewatkan

Allah tidak menyebutkan bahwa kebahagiaan adalah kesehatan, kekayaan, jabatan, atau kedudukan Anda yang baik. Namun, menerima rahmat dan kesenangannya memang kebahagiaan sejati, yang jauh lebih besar dari yang disebutkan di atas, karena jika seseorang 
menerima rahmat dan ridha Allah, dia akan mendapatkan lebih dari ini, yaitu tidak. Bentuk hukuman Allah. Ini sangat menyakitkan, surga penuh kegembiraan.

Seperti firman Allah Q.S. Ghafir ayat 9 sebagai berikut:

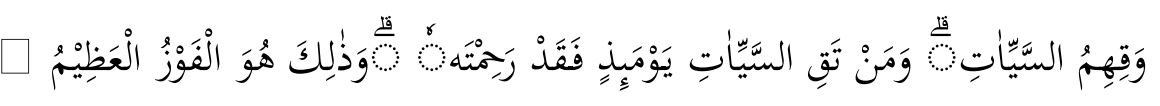

Artinya: "Dan peliharalah mereka dari (bencana) kejahatan. Dan orang-orang yang Engkau pelihara dari (bencana) kejahatan pada hari itu, maka sungguh, Engkau telah menganugerahkan rahmat kepadanya dan demikian itulah kemenangan yang agung."

\section{Kesimpulan}

Kebahagiaan pada karyawan wanita usia madya itu ada dua aspek, yaitu aspek kognitif dan aspek afektif. Dari aspek kognitif subjek S dan A memiliki kepuasan hidup yang berbeda, jika subjek S belum cukup puas dengan hidupnya sedangkan subjek A sudah merasa cukup, walaupun demikian baik subjek $S$ dan A selalu sama-sama bersyukur dengan apa yang mereka dapatkan. Aspek afektif pada subjek S yaitu memaknai kebersyukuran dan kebahagiaannya dengan mengambil sisi positif dari pengalaman hidup yang subjek $S$ jalani, sedangkan aspek afektif pada subjek A lebih memaknai kebersyukuran dan kebahagiaanya dengan lebih mendekatkan diri kepada Allah. Aspek kebahagiaan yang lain itu ada aspek acceptance (sikap meneima), yaitu sikap menerima dan bersyukur oleh kedua subjek dengan takdir yang Allah telah tentukan. Kemudian ada aspek affection (kasih sayang), yaitu perasaan bahagia yang dirasakan subjek dari penerimaan diri oleh orang lain. Subjek S dan A mengaplikasikan rasa kasih sayangnya dalam keseharian yaitu dengan saling berbagi terhadap sesama, serta saling menghormati terhadap sesama teman kerja atau lingkungan sosial. Yang terakhir aspek achievement (prestasi), yaitu perasaan bahagia yang muncul karena ketercapaiannya tujuan kedua subjek. Tercapainya sebuah tujuan didapatkan pada subjek A yaitu tujuan ingin memiliki kembali keluarga yang harmonis, sedangkan tujuan subjek $S$ yaitu ingin memiliki usaha sendiri dan melihat anak-anaknya sukses belum tercapai.

Menurut subjek S faktor-faktor yang mempengaruhi kebahagiaan adalah uang karena dengan memiliki banyak uang subjek $S$ bisa mencukupi kebutuhannya dan bisa memiliki usaha sendiri. Perkawinan mempengaruhi kebahagiaan karena dengan memiliki suami atau 
pasangan subjek S merasa kebahagiaannya sempurna. Kehidupan sosial mempengaruhi kebahagiaan karena dengan berkumpul dengan teman-teman atau keluarga menurut subjek $\mathrm{S}$ bisa memberi dampak positif untuk kebahagiaannya. Kesehatan mempengaruhi kebahagiaan subjek $S$ karena kesehatan menjadi hal penting yang harus dijaga pada usia madya agar bisa merasakan kebahagiaan. Dan agama mempengaruhi kebahagiaan subjek karena dengan beribadah subjek S bisa mendapatkan ketenangan batin. Sedangkan menurut subyek A faktorfaktor yang mempengaruhi kebahagiaan adalah uang, karena dengan memiliki uang subjek A bisa membantu mencukupi kebutuhan keluarga. Perkawinan mempengaruhi kebahagiaan subjek A karena dengan pernikahan dengan orang yang tepat bisa menimbulkan perasaan aman dan nyaman. Usia bisa mempengaruhi kebahagiaan karena dengan bertambahnya usia subjek A bisa lebih banyak bersyukur agar bisa merasakan kebahagiaan dengan bertambahnya usia. Kesehatan menjadi pengaruh penting pada subjek A karena menurut subjek A untuk bisa bahagia yang paling penting adalah bisa diberi kesehatan. Dan agama mempengaruhi kebahagiaan menurut subjek A karena dengan hidup religius subjek A bisa lebih bahagia dan tenang hidupnya.

Saran

Berdasarkan kajian yang telah dikemukan di atas maka peneliti merasa perlu menyampaikan beberapa saran guna meningkatkan kajian-kajian di bidang Psikologi di masa mendatang. Saran yang dapat diberikan yakni pada wanita yang berusia madya dapat mengetahui cara untuk meningkatkan kebahagiaannya baik melalui aspek kognitif atau aspek afektif. Untuk karyawan Kumala Laundry Kota Banjarmasin mampu meningkatkan faktorfaktor yang mempengaruhi kebahagiaannya, serta Diharapkan peneliti selanjutnya yang akan meneliti tentang kebahagiaan pada dewasa madya yang bekerja, diharapkan supaya mengkaji aspek kebahagiannya lebih mendalam dan menyeluruh dengan memperhatikan kedalaman dalam wawancara dan observasi. Selain itu, membandingkan dengan jenis kelamin yang berbeda. 


\section{Referensi}

Abdullah, M. Ma'ruf. Manajemen dan Evaluasi Kinerja Karyawan. Yogyakarta: Aswaja Pressindo, 2014.

Abintara, Hendra Bagus. "Pengaruh Spiritualitas Terhadap Kebahagiaan Melalui Kebermaknaan Hidup Pada Tentara Nasional Indonesia Bintaldam V/Brawijaya". Skripsi. Malang: Fakultas Psikologi Universitas Islam Negri Maulana Malik Ibrahim Malang, 2015.

Al-Banjari, Rachmat Ramadhana. The Route Of Happiness. Jogjakarta: DIVA Press, 2009.

Bakkar, Abdul Karim, 86 Langkah Meraih Kebahagiaan Hidup. Jakarta: Grafindo Khazanah Ilmu, 2008.

Basrowi dan Suwandi. Memahami Penelitian Kualitatif, Jakarta: Rineka Cipta, 2008.

Departemen Agama RI. Al-Qur'an Terjemah. Jakarta: Pustaka Al-mubin, 2013.

Departemen Pendidikan Nasional. Kamus Besar Bahasa Indonesia. Jakarta: PT. Gramedia Pustaka Utama, 2008.

Deviana Maharani. “Tingkat Kebahagiaan (Happiness) Pada Mahasiswa Fakultas Ilmu Pendidikan Universitas Negeri Yogyakarta", Skripsi. Yogyakarta: Universitas Negeri Yogyakarta, Jurusan Psikologi Pendidikan dan Bimbingan, 2015.

Fibrati Islami. "Konsep Kebahagiaan Menurut Imam Al-Ghazali". skripsi. Pekanbaru: Fakultas Ushuluddin Universitas Islam Negeri Sultan Syarif Kasim Riau, 2015.

Haris Herdiansyah. Metodologi Penelitian Kualitatif untuk Ilmu Psikologi. Jakarta: Salemba Humanika, 2015.

Kusdiyati, Sulisworo dan Irfan Fahmi. Observasi Psikologi. Bandung: PT. Remaja Rosdakarya, 2015.

Mahmudah. "Faktor-Faktor Kebahagiaan (Happiness) Bagi Wanita Lajang Dewasa Madya". Skripsi. Surabaya: Jurusan Psikologi, Universitas Negeri Sunan Ampel Surabaya, 2016.

Miles, Matthew B, "Analisis data kualitatif: buku sumber tentang metode-metode baru/Matthew B, Miles dan A. Micheal Huberman: penerjemah Tjejep Rohendi Rohidi", (Jakarta: Penerbit Universitas Indonesia, 1992.

Miwa Patnani. “Kebahagiaan Pada Perempuan” Jurnal Psikogenesis. Vol. 1, No. 1, Desemeber 2012.

Moh Nazir. Metode Penelitian. Jakarta: Ghalia Indonesia, 2014.

Moleong, Lexy J. Metodologi penelitian kualitatif. Bandung: PT. Remaja Rosdakarya, 2012.

Pasaribu, Rizky Fatimah, "Pengaruh Pemberian Informasi Terhadap Kecemasan Wanita Yang Menghadapi Menopause". Skripsi. Medan: Fakultas Psikologi Universitas Medan Area, 2016. 
Raharjo. Pengantar Ilmu Jiwa Agama. Semarang: Pustaka Rizki Putra, 2012.

Rahmadi. Pengantar Metodologi Penelitian. Banjarmasin: Antasari Press, 2011.

Rahman, Putri Aulia. "Hubungan Religiusitas Dengan Kebahagiaan Pada Lansia Muslim". Skripsi. Medan: Fakultas Psikologi Universitas Sumatera Utara, 2012.

Sa'abah, Marzuki Umar. Bagaimana Awet Muda Dan Panjang Usia. Jakarta: Gema Insani Perss, 2001.

Saebani, Afifuddin dan Beni Ahmad. Metodologi Penelitian Kualitatif, Bandung: Pustaka Setia, 2009.

Saifuddin Azwar. Metode Penelitian Psikologi, Yogyakarta: Pustaka Pelajar, 2003.

Saifuddin Azwar. Metode Penelitian. Yogyakarta: Pustaka Pelajar, 2003.

Seligman, Martin E.P. Authentic Happiness. Bandung: PT. Mizan Pustaka, 2005.

Silaban, Santi Marini. "Hubungan Antara Kepuasan Pernikahan Dengan Empty Nest Syndrome Pada Dewasa Madya Dikelurahan Tanjung Beringin Dusun VI". Skripsi. Medan: Fakultas Psikologi Universitas Medan Area, 2019.

Sugiyono. Memahami Penelitian Kualitatif. Bandung: Alfabeta, 2013.

Sulisworo Kusdiyati dan Irfan Fahmi. Observasi Psikologi. Bandung: PT. Remaja Rosdakarya, 2015.

Wahidin, "Spiritual dan Happiness Pada Remaja Akhir serta implikasinya Dalam Layanan Bimbingan dan Konseling". Journal of Innovative Counseling: Theory, Practice and Research. Vol.1, No.1, Januari 2017.

Yudrik Jahja. Psikologi Perkembangan. Jakarta: KENCANA, 2012.

Https://kumalalaundry.co.id diakses pada tanggal 12 oktober 2018.

\begin{tabular}{|l|l|l|l|l|}
\hline Submit & Review & Revisi & Diterima & Publish \\
\hline $25-01-2021$ & - & - & $04-11-2021$ & $04-02-2022$ \\
\hline
\end{tabular}

\footnotetext{
Nangimatus Sa'adah, Siti Faridah dan Yulia Hairina

Program Studi Psikologi Islam

Fakultas Ushuluddin dan Humaniora

Universitas Islam Negeri (UIN) Antasari Banjarmasin

Email : iin.saadah07@gmail.com
} 